\title{
Economic Crisis and Euroscepticism: \\ A Comparative Study of the Hungarian and Italian Case (1990-2013)
}

\author{
ANNA MOLNÁR
}

$\frac{\text { DE }}{\text { G }}{ }^{\text {DE GRUYTER }}$

Politics in Central Europe (ISSN: 1801-3422)

Vol. 12, No. 3

DOI: 10.1515/pce-2016-0017

\begin{abstract}
This comparative paper examines the reasons and the features of the rising Euroscepticism in Italy and in Hungary in the light of economic, financial, and political crisis. The financial crisis became the main focus of the political debates and discourses among the Italian and the Hungarian political parties between 2008 and 2013. In Italy and Hungary, Euroscepticism is still on the rise. In the first chapter, I will shortly summarise the conceptual framework of Euroscepticism. In the second chapter, I provide an overview of the way Hungarian and Italian political discourse has envisioned Europe in the post-bipolar, or post-Maastricht, period that began in the early 1990s. The fall of the Berlin wall had a decisive impact on the domestic politics of Hungary and Italy, and subsequent international changes created the basis for different forms of transitions in both countries. Hungary left behind dictatorship and the one-party system to create a functioning democracy, whereas Italy experienced the end of the political party system of the "First Republic," giving birth to the highly promising "Second Republic."
\end{abstract}

Key words: Italy, Hungary, European Union, Euroscepticism, integration, domestic politics

\section{Introduction}

This comparative paper examines the reasons and the features of the rising Euroscepticism in Italy and in Hungary in the light of economic, financial, and political crisis. The financial crisis became the main focus of the political debates and discourses among the Italian and the Hungarian political parties 
between 2008 and 2013. In Italy and Hungary, Euroscepticism is still on the rise (Molnár 2011; Molnár 2012; Molnár 2013)

In the first chapter, I will shortly summarise the conceptual framework of Euroscepticism, which is a negative or sceptical attitude towards the European integration process. The literature addresses both Euroscepticism at both the party and individual levels, as well as soft and hard Euroscepticism; that is, sceptic public opinion towards the EU as a whole or the membership of a country in the EU, versus public scepticism of only one common policy. In the second chapter, I provide an overview of the way Hungarian and Italian political discourse has envisioned Europe in the post-bipolar, or post-Maastricht, period that began in the early 1990s. The fall of the Berlin wall had a decisive impact on the domestic politics of Hungary and Italy, and subsequent international changes created the basis for different forms of transitions in both countries. Hungary left behind dictatorship and the one-party system to create a functioning democracy, whereas Italy experienced the end of the political party system of the "First Republic," giving birth to the highly promising "Second Republic."

This time period can also be considered the post-Maastricht era, because European integration has had an increasing impact on domestic politics and on the national party system in the years since the Maastricht Treaty (Mair 2000). As the EU has become more and more integrated and, as a result, complicated, society has become increasingly critical of the union, rising questions about the perceived democratic deficit, information deficit, and communication deficit of the EU, as well as other issues.

The following section focuses on individual and party attitudes towards the EU public opinion towards the membership of Italy and Hungary, and the opinion of the governments and political parties about the institutional reform of the European Union based on primary and secondary sources. In order to analyse Euroscepticism, Eurobarometer surveys are used. For both Hungary and Italy, the Euro has become a modernisation symbol, and a certain "EU-enthusiasm" or Euro-enthusiasm can be observed in order to join the Eurozone (Italy) or EU (Hungary). Following the realisation of these projects there has been an ever growing euroscepticism (Hungary, Italy) or Euro(-coin)-scepticism (Italy), and less and less confidence due to waning economic advantages. The "euro" in Euroscepticism refers to the European integration, and "Euro" in Euro-scepticism refers to the common currency. Similarities between two major Italian and Hungarian politicians, Berlusconi and Orbán, make the countries valuable cases for comparison. Indeed, both leaders have pursued populist, soft-Eurosceptic policies with respect to media laws, migration policy, and security policy (Körösényi -Patkós 2015)

In the third chapter, I focus on the causes of growing Euroscepticism (party level or individual Euroscepticism) in Italy and in Hungary as a consequence of 
the financial and economic crisis 2008). In my research I analyse the post-crisis period, which more or less coincides with a second transition period.

\section{Table 1: Transitions}

\begin{tabular}{|l|l|}
\hline Italy & Hungary \\
\hline $1947-1992 / 93$ First Republic & 1949-1989 Second Republic \\
\hline 1992/93-2011/13 "Second Republic" & 1989-2012 Third Republic \\
\hline 2011-13 beginning of the „Third republic"? & 2012- Forth Republic \\
\hline
\end{tabular}

The importance of my research field is confirmed by the fact that the first draft of the new Global Strategy of the EU in 2015 emphasised that "The European Union, too, is more contested. The financial and economic crisis has posed a serious challenge to European unity. Many Europeans have been hit by the crisis, and have come to view themselves as losers of globalisation. This is feeding certain constituencies within Member States which express criticism of, if not outright opposition to, the European project. This trend, which often blends legitimate grievances with a dangerous mix of nationalism, populism, protectionism and even racism, is exposing a new rift within the EU and bringing new anti-establishment forces to the fore. It is a divide between elites and citizens manifested in voter disaffection, and a lack of trust in public institutions and policies. (...)

A more contested EU is bringing about broader external challenges. The rise of nationalism, protectionism and illiberalism could expose European nations to the lure of anti-democratic models promoted from outside. Populism and racism could feed fortress Europe mentalities, undermining credible enlargement and neighbourhood policies, forthcoming migration and mobility policies, and even trade liberalisation." (European External Action Service 2015: 8)

\section{Euroscepticism}

Euroscepticism is a negative or sceptical attitude towards the European integration process (Taggart - Szczerbiak 2001). Euroscepticism exists at both the party level and the individual level. Gabel and Whitten stated that the worsening economic situation has had a positive impact on the level of individual Euroscepticism, as in it has increased euroscepticism (Gabel - Whitten 1997: 81).

A division can be mentioned between soft and hard euroscepticism. Soft euroscepticism includes, for example, opposition to certain policies of the EU. Those who express revulsion against the political or economic 'deepening' of the EU (e.g. objection against the introduction of the Euro) are also counted among 'soft sceptics'. In short, those who belong to the soft wing of eurosceptics are not against European integration, but have different opinions about par- 
ticular measures. They attach primary importance to the promotion of national interest. In contrast, the representatives of the hard euroscepticism are totally against the political and economic integration, and they even oppose the EU membership of their own country (Taggart - Szczerbiak 2001: 8). They generally express criticism against capitalism, liberalism and socialism considering these as certain power tools of the EU.

There is a large variety of levels and opinions concerning the European integration process. Kopecky and Mudde (2002) established the categories of Euroenthusiasts, Eurosceptics, Europragamatists, Eurorejects. Analysing Italian political parties, Conti and Verzichelli defined five different types of attitude towards European integration. According to their classification, the centre-left parties (PPI, DS, and later the PD) represent identity Europeanism, the extreme left $(\mathrm{RC})$ represent hard euroscepticism, centre-right parties (FI, AN) display functional Europeanism and soft euroscepticism, and the Extreme right (LN) float somewhere between functional, soft, and hard Euroscepticism (Conti 2003).

Since 2012 the Hungarian Europe Society has been conducting a regular monitoring research project to examine the attitude of the Hungarian political parties towards the EU, and created its own PERC-index categories. 1 represents the "total rejection of any kind of European integration" and 10 "the complete acceptance of a full-blown European federalism" to measure their attitude between June 2009 (European elections) and mid-2012. In the PERC-index 1. is Euro-destructive, 2. is Europhobe, 3. is Hard eurosceptic, 4. is Soft eurosceptic, 5. is Europessimist, 6. is Europragmatist, 7. is Soft europragmatist, 8. is Euro-constructive, 9. is Eurooptimist and 10. is Federalist. The executive summary of the project stated that no Hungarian parliamentary party received 1 (real Euro-destructive which would refuse to participate in EP elections) or 10 (real federalist which offers a coherent federalist vision), that is the two opposite categories. (Európa Társaság 2013: 5)

\section{First Transition Following the Collapse of the Bipolar World and the Post-Maastricht Period}

\section{Party attitudes towards the EU in Italy}

In Italy up to 1990 s, in reality European-level policy-making did not involve competition between large, oppositional coalitions, mainly due to the lack of the political alternation between governments of different political opinions and due to bipartisan EU-policy since the 1970s. It was only after the collapse of the Eastern Bloc, the actions of "mani pulite" and the electoral reform (1993) that the two large opposing governmental coalitions took shape. The introduction of the majority principle in the electoral system contributed to the formation 
of party coalitions which were more efficient in securing a stable governmental operation, thus creating the basis for the real political alternation of governments. The events taking place in Italy during the early 1990s were considered by many as a "transformation" which marked the end of the "First Republic" and the birth of the highly promising "Second Republic" (Fabbrini 2009).

Although the collapse (1989-1991) of the Eastern Bloc served as a fundamental impetus for change, the real political avalanche was launched by the corruption scandal that broke out around the Italian Socialist Party. In the case of Italy, however, it is not possible to speak about the birth of the new Republic in the traditional political or constitutional sense, as this process was not due to the elaboration and approval of a new constitution, but rather was the result of political changes concerning parties, the political elite and the party system. In the midst of major changes to the party system, smaller parties almost totally disappeared while the bigger ones were transformed to a large extent, with their support dropping. This remarkable transformation of the political and party system was connected to the renewal of the political elite and helped the creation of the bipolar party-system.

All of the main political parties have expressed a pro-European approach since the 1970s, but during the post-Maastricht Treaty period, different levels of Euroscepticism have emerged. On the left, the major successor of the PCI (Italian Communist Party), the PDS (Democratic Party of the Left, 1991-1998), later transformed into DS (Democrats of the Left) (1998-2009), emphasizing the social and democratic aspects and supranational federalist vision of the integration concentrating on welfare and social issues. The PDS/DS, a founder of the Party of European Socialists (PES), expressed this opinion during the electoral campaign of the 1999 EP elections with its political slogan: 'yes to a market economy, no to a market society'. The Party for Communist Refoundation (PRC), the smaller of the two successor parties to the PCI, represented a different model of the integration. It expressed its critical opinion about the deepening of the integration and the institutional reform, voting against the Maastricht Treaty and later the European Constitutional Treaty, and criticising the wider incompetence of the EU. The PRC wanted and felt the absence of the articulation of some basic principles, like the ban of all wars and the creation of a full-employment economy. (Bardi 2007: 6-7; Conti 2003: 25)

The other main pro-European centre-left party, the PSI became one of the main losers of the party system crisis due to the actions of the so called 'Mani Puliti'. The SDI (Italian Democratic Socialists), which was the most important successor of the PSI, maintained the pro-European, federalist attitude of its predecessor and lost significant support. The left and liberal Radical Party was also pro-European, and in its 2004 statute stated the necessity to strengthen 'the liberal, liberist, and libertarian struggle for liberal revolution and for the United States of Europe'. The party supported the federal development of the 
integration based on the principle of subsidiarity in order to make decisions closer to the people. The 2000 statue of the Greens expressed a similar, pro-European opinion: 'The Greens are those who work for the political unity of a Europe based on the principles of democratic federalism and subsidiarity.' They represents that the environment is a key issue for the creation of the political unification of the Union. (Bardi 2007: 7)

The centre-left parties (e.g. DS, PPI) have been the most devoted supporters of the deepening European integration since the 90s with the aim of creating a supranational, federal union, highlighting the importance of a common European identity. Following the collapse of the Italian party system, the Italian Christian Democracy (DC) split into two major factions that headed in different political directions. The right wing of the DC created the CCD (Christian Democratic Centre) and the CDU (the United Christian Democrats, which later became the UDC, Union of Christian and Centre Democrats). The successors of the DC were all pro-European and in favour of the deepening of the European integration. The left wing of the DC founded the Italian Peoples Party (PPI). The PPI later played an important role in the creation of the centre-left Margherita.

In 1993, leaving a political vacuum behind, the Italian Christian Democracy finally dissolved, and the voter support of the successor parties also significantly decreased. Consequently, the vacuum in the internal politics was filled suddenly by a new type of political parties. On the right side of the political spectrum during the 1990s, three new parties emerged that attracted most of the voters with a right-wing orientation: Forza Italia (FI), National Alliance (Alleanza Nazionale - AN) and the Northern League. This process naturally did not occur without any precedents as the routes of the Northern League can be traced back already to the 80s. At the same time, the National Alliance grew out of the Italian Social Movement (MSI, Movimento Sociale Italiano). In 1993 a new party emerged to oppose the centre-left coalition: Forza Italia. This party indeed constituted a totally new, unprecedented political construction. The huge vacuum in the right-wing was finally filled by the real-estate and media magnate Silvio Berlusconi.

At the beginning of the 1990s, Italy had to face serious economic problems. In 1992, the Lira was deflated by 7 percent (and then 30 percent), so, although only temporarily, Italy had to leave the European Monetary System. Simultaneously, other macroeconomic indicators of the Italian economy, such as the foreign trade balance and the government debt, showed worsening trends, while Italy's ability to join the European common currency also became less certain. During the first Berlusconi government in 1994, the Foreign Minister, Antonio Martino, criticised the EMU project. He emphasised that 'the convergence was neither a necessary nor a sufficient condition for monetary unification'. He also considered it necessary to renegotiate the convergence criteria of the Maastricht treaty. The Prime Minster Silvio Berlusconi also proposed the renegotiation of 
the TEU so that Italy could join the EMU without fulfilling the convergence criteria. (Quaglia 2003: 11)

However, by the middle of 1990s, following the 1996 elections, the new centre-left 'Olive-tree Coalition' managed to re-stabilise the Italian economic balance. In November 1996, the Lira re-joined the European Monetary System. The "Olive-tree Coalition' considered one of their priorities to fulfil the euro convergence criteria (Maastricht Criteria). (D’Alema 1998; Ciampi 2000a: 203-205) In this period, the problems of the Italian economy made it uncertain whether Italy could remain at all an important member of the European Union. The Prodi government considered their primary mission to conclude the necessary reforms. They set as their goal the elimination of economic problems and the reestablishment of the prestige of the political elite. They also sought to fulfil the euro convergence criteria, lead Italy back into the European Monetary System, get admitted into the Euro Zone, and reform of the public sphere and political institutions. (D'Alema 1997: 157) In the year 1997, in order to comply with the euro convergence criteria, without any resistance by the Italian public, they introduced a so called 'one-time Euro tax' to be valid only until the fulfilment of the criteria had been achieved. Owing to the success of the economic policy, Italy became a member of the Monetary Integration, which the centre left government could account for as a great achievement when it was finally approved in Brussels on May 1, 1998. (Horváth 2000: 550-553) After the introduction of the Euro, analysts found that contrary to earlier difficulties, participation in the European Monetary meant a serious advantage for Italy; the interest rates for example decreased at a higher speed than in other states, and as analysts claimed, the 2000 oil crisis also impacted the Italian economy less than it would have were Italy to have faced the crisis on her own (Vaciago 2001: 208).

While after the introduction of the Euro several political fields (e.g. inflationary and monetary policies) became part of the common policies, several others remained under the authority of national governments (e.g. employment policy, technological development, tax policy and social policy). National governments remained responsible for the reform of the latter political fields. In Italy, the execution of reforms was to a large extent made difficult by the economic problems that had cumulated during the preceding decades (e.g. the problems occurring in the Mezzogiorno, the high government debt and the relatively low $\mathrm{R}+\mathrm{D}$ subsidies). Italian politicians (e.c. Massimo D'Alema, Carlo Azeglio Ciampi) worried about the country's exclusion from the important issues concerning the integration in case of staying out of the Euro Zone (D'Alema 1998; Ciampi 2000a). Already during the first two Berlusconi governments (1994), the government began to drift away from the traditional EU policy. The new government, through a more determined emphasis on national interests, stopped representing the traditional 'follower' EU policy of its predecessors. After the inauguration of the second Berlusconi government, communications concern- 
ing the Euro seemed to underpin the worries of those who had concerns about the future of the integration. In early January 2002 the debate between some members of the government, like Umberto Bossi and the minister of foreign affairs concluded in the resignation of the foreign minister, Renato Ruggiero. During the years following her accession to the Euro Zone, Italy was still able to maintain the macro-economic indicators required by the convergence criteria (La Repubblica 2002; Corriera della Sera 2002).

\section{Hungary}

Following the collapse of the bipolar world, EC/EU membership has become the modernisation symbol of a prosperous, democratic and European Hungary, which has always been an organic part of Europe. In the period of the collapse of the socialist state, the primary goal of the main Hungarian political parties was immediate accession to the European Union. As Hungary, during the eighties, had a special, albeit limited, experience of liberalisation in economic and political fields, it was considered the best prepared country in the region among the first group of states to join the EC/EU.

During the first free election campaign in 1990 there was a common agreement among the political parties that the most important foreign policy goal was early Hungarian membership in the EU. There was only one anti-European political party: the communist Workers' Party, which was an extra-parliamentary movement following the first free elections and the smaller of the two successor parties to the Hungarian Socialist Workers' Party. Apart from this movement, all the mainstream parties that formed during the period of peaceful transition in the period 1987-1989 were pro-European, but some differences can be identified in their political goals regarding EU membership and integration.

The Hungarian Social Democratic Party (HSDP) and the Hungarian Socialist Party (HSP, the main successor party to the Hungarian Socialist Workers' Party) emphasised concentration on welfare issues, social democratic aspects, and a supranational federalist vision of integration. As a consequence of the 1990 electoral failure of the HSDP, the traditional social democratic party was not able to form a parliamentary party. Following the transitory period, from 1991 onwards the socialist party (the larger of the two successor parties to the Hungarian Socialist Workers' Party) became one of the most important mainstream parties, and by 1993 had transformed into a centre-left party of a 'social democrat' or 'social liberal' kind. As a testimony of its pro-European attitude, the HSP frequently called the attention of the Western European public and politicians to the very important role of Gyula Horn, the former Minister of Foreign Affairs, in the German unification (Navracsics 1997: 10-11; Mayr 2009). The pro-EU left-wing actors (e.g. HSP and the Alliance of Free Democrats (AFD)), have considered the accession as anti-nationalistic and part of the modernisation 
project. These parties have emphasised the economic advantages of membership, and the finalisation of the change of the regime.

The AFD and Fidesz (Alliance of Young Democrats), concentrated on the neoliberal, capitalistic approach of the European economy based on free trade principles. For the liberals, EU membership was the only way to modernise the country. After a short transitional period of sharing similar visions concerning the EU, their political paths diverged: the AFD, while turning into an authentic social-liberal party, started to concentrate on the social democratic aspect of the EU, whereas Fidesz moved towards a more conservative interpretation of Europe, defining itself as a liberal conservative party (Navracsics 1997: 12).

Conservatives focused on the political aspects of European integration based on the conception of a Europe of nations. The Hungarian Democratic Forum (HDF), the Independent Smallholders' Party (ISP), and the Christian Democratic People's Party, defined Europe by its cultural aspects, emphasising that Hungary was an organic part of the West, but 'it was violently isolated from its natural environment for forty years' (Navracsics 1997: 13). Thus, their political slogan was not 'the road to Europe', but return to Europe.

\section{Individual attitudes towards the EU or the introduction of the Euro}

\section{Italy}

The deepening of European integration was not only supported by the changing governments, but also by the Italian public. Among the countries of the EU, it was Italy whose population supported this process most. The future of Italy was considered as dependent on the country's role in the EU. The Italian public has been an ardent devotee of integration, even more so than the EU average.

In 2004 the Flash Eurobarometer showed the confidence of Italians in the Constitutional reform of the European integration. The majority of Italians ( 82 percent) seemed to agree that without a Constitution, the Institutions of the European Union could reach a deadlock, so they recognised the usefulness of a Constitution (European average 69 percent) (Eurobarometer 2004).

Italians traditionally have greater confidence in EU institutions than in their national ones. In Spring 2005, Eurobarometer survey showed that 56 percent of Italians trusted the European Union, while 33 percent who did not (Eurobarometer 2005: 2). In 2005 the level of support was lower than in June-July 2004, when more than 90 percent of Italians supported the Constitution, and accordingly viewed constitutional reform positively. However, only 15 percent of Italians knew the text of the Constitution (EU-25 WATCH No. 2. 2006: 69). As showed by the Eurobarometer 2006 (Spring), 78 percent of the Italians were not familiar with the whole contents of the European Constitution, or had never 
heard of the Constitution itself. It is important to underline that the average level of knowledge of the texts of the Constitution was quite low. However, 78 percent of Italians agreed with the statement that the adoption of the Constitution would make the EU more democratic, while 76 percent agreed it would make the union more efficient and more transparent.

According to the Eurobarometer survey after the French and Dutch 'no' referendum about the European Constitution, the relative majority of the Italian interviewed (37 percent) stated that EU Member States should continue the ratification process. And 33 percent answered that the European Constitution should be renegotiated. Only 6 percent of Italians said that the European Constitution should be abandoned, while 23 percent abstained from answering. In spring 2006 ' 56 per cent of the Italian sample considers that for Italy to be part of the EU is a good thing' (Eurobarometer 65 2006: 3-5).

For the majority of Italians the EU membership was still an advantage. However, during that time period, a wider scale of opinions regarding EU issues can be noticed, and there was a more critical approach in the public debate. According to the 2007 Spring Eurobarometer survey, 74 percent of Italians surveyed agreed with the opinion that 'every European decision is the subject of negotiations in which the opinions of the national governments of all Member States are taken into account'. Furthermore, 53 percent of Italians thought the 'voice of Italy counts in Europe', and 55 percent anticipated 'that Italian influence in the EU will be even stronger in the future'. Italians decisively support the European management instead of the national one in certain policies such as foreign and defence affairs (67 percent), energy (68 percent), immigration (67 percent), the fight against crime (63 percent), and environment (60 percent). Italians agreed with the concept of the so-called 'Multi-speed Europe' where those member states which are prepared to strengthen the level of integration of a common European policy in certain areas could do so without waiting for the others (Eurobarometer 672007 : 3-5).

A few months before abandoning the European Constitution, 72 percent of Italians still had a positive approach to the Constitutional Treaty, and 68 percent of interviewees were optimistic about the future of the EU. The majority thought that the 'European Union in the next 50 years will have a common army and will be a leading diplomatic power in the world'. 72 percent agreed with the notion that the European Union should have its own Foreign Minister. (Eurobarometer 67 2007: 3-5) In 2008 the relative majority of Italians still had a positive opinion about Italy's membership in the EU, though a clear decline (from 50 percent to 39 percent) can be noticed. 37 percent of Italians thought about EU membership in a positive way, believing that Italy had benefited from its membership in the union. Half of the interviewees believed that the Italian position was not taken into account at the European level. It is important to underline that only 15 percent of Italians thought that MEPs paid attention to 
their views and 14 percent thought the same about the European Commission. 78 percent of Italian believed that national institutions were not transparent, and 50 percent thought the same about European institutions. Still, the relative majority of Italians maintained confidence in the European Union (40 percent), yet the number of sceptics was growing (Eurobarometer 69 2008: 2-3).

\section{Hungary}

Following the collapse of the communist regime, the image Hungarians formed of Europe was determined by their economic and political expectations. In the referendum held on the issue of EU membership (2003), the turn-out was 45.6 percent, and 83.76 percent of the voters said 'yes'. ${ }^{2}$ So, despite relatively low participation, the Hungarian population voted overwhelmingly for accession. According to Miklós Sükösd, the low turnout might have been caused by the lack of genuine debate in the political sphere. That is, there had been no serious arguments for or against the accession of Hungary, and all this had led to a staggeringly low interest in the European issues. The communication campaign started abruptly, and rather late, which also contributed to the communication deficit (Sükösd 2005).

It is necessary to mention that the communication deficit was not only a Hungarian problem, but also a problem that practically all the member states confronted. Nevertheless, it seems important to examine the specific reasons for the growing disappointment among the Hungarian population in the years following the accession. István Hegedűs emphasized that the Hungarian press was not able to convey the gravity of the Hungarian accession and the European integration (Hegedüs 2005). The adoption of the acquis by the Hungarian administration did not create a heated debate in the press, except for during the final phase of the negotiation process, when it was mainly common issues (like the impact of accession on the use of poppy-seed as food ingredient) that appeared in the Hungarian media (Uitz 2008: 44).

In 2005, a poll was carried out in order to examine what Hungarians were thinking about the EU membership, and its local consequences (Medián 2005). Similarly to some other opinion polls of the period, 75 percent of the subjects were for the Hungarian membership, and 25 percent were against it. The number of supporters increased linearly with the educational level of the subjects asked, i.e. among those who had no secondary degree, the proportion of supporters was 70-75 percent, and in the case of professionals, this proportion was 80 percent (Kormány 2006: 89).

2 Czech Republic: turnout -55.21 percent, yes -77.33 percent; Poland: turnout -58.85 percent, yes -77.45 percent; Slovakia: turnout -52.15 percent, yes -92.46 percent; 
According to Marján, one of the main reasons for Hungarians' sense of disappointment with the union was that prior to the accession, there were several myths among the Hungarian population about the fast rise of salaries, new employment possibilities and material subsidies similar to those enjoyed by beneficiaries of the Marshall plan. The potential EU membership of Hungary assured financial resources from the EC/EU. In spite of this, Hungarians were also afraid of losing sovereignty as well as the onset of fatal competition due to the opening of the markets (Marján 2006: 5).

These fears can be traced back to three main sources: a) even in spite of the intensive change-over to market economy, free market conditions could not yet come to life; b) market players were smaller and less developed, and so they felt insignificant in comparison to competitors. Finally, there was quite a lot of fear that costly regulations protecting the environment, consumers, and the labour force would be introduced. Not all the fears were well founded. In the spheres of industry and services, for example, no serious crisis took place after May 1, as most of the development had already taken place during the accession process through the liberalization of commercial and market contacts and legal harmonisation. And, most importantly, Hungary obtained real voting rights in the decision making process if the EU.

Another cause for fear regarding the accession for Hungarians was the issue of sovereignty. This arose from the fact that Community Law has primacy over national legislation. Like every other member, Hungary also gained the possibility of enforcing the country's interests as a member with voting rights. In the globalizing world, more and more problems can only be solved as a member of a larger international community. Moreover, for a small country like Hungary, this is the only road to success. Also the curious paradox can be mentioned that this fear occurred after Hungary's full adoption, in the period of accession, of the 80 thousand page documentation of the acquis that had been formulated without the country's representative participation in the EU legislation process. In fact, the real challenge for all the new members has been hidden in the process of convergence to EU average income (Marján 2006: 15).

The Eurobarometer of October 2006 already clearly showed Hungarian society's disappointment with the EU accession. Since spring of that year, the support for EU membership has dropped by a further 10 percent, reaching 39 percent, probably due to the country's domestic political issues (elections, growing economic problems, general feeling of uncertainty).

In 2006, as seen from the Eurobarometer figures, trust in the institutions of the European Union was the highest among new member states. 82.5 percent of those who were supporters of Hungary's membership thought that it meant a guarantee against the return of dictatorship. Among those, however, who were against it, agreement with this statement registered only 63.5 percent support. As to the statement that 'the sovereignty of Hungary suffered with the acces- 
sion of the country', 76 percent of those against the membership claimed they agreed, while amongst those who supported the accession, this ratio was only 43 percent. There was a slight majority among the subjects of those who though that the country suffered a disadvantage as a consequence of the accession (53 percent), leaving merely 47 percent claiming that, on the whole, the accession brought about an advantageous result (Kormány 2006: 90).

The long-term benefits of accession were not debated. However, in the short run, the negative aspects of the process were felt by those who were threatened by existential uncertainty: something which was least applicable to the strata with the highest level of education. 54 percent of those interviewed agreed with the statement that 'Hungary does not have a word in the EU legislation', showing that a significant portion of the population was not aware even of the most basic facts about the European Union. (Kormány 2006: 91).

The issue of sustaining and preserving national traditions, as well as the alleged threat against them, became part of everyday discourse during the process of accession. This was reflected in the number of respondents who agreed with the statement, 'The EU will threaten national traditions' (40 percent). 36 percent of those who claimed to follow the daily news reports regularly thought that the EU meant a threat to traditions, while this portion was 44.6 percent among those who reported they did not watch daily news. This shows a relatively low impact of the media interpretations of the accession on the public opinion. Nevertheless, the majority of respondents claimed that the accession would improve upon the conditions of the pre-accession period, in the fields of the country's security (62 percent), human rights (57 percent), legal security (52 percent), and development of the economy (51 percent). Opinions on the following fields already reflected slight doubts as to the possible positive consequences: stability of democracy ( 49 percent) and financial stability (47 percent) (Kormány 2006: 94-5). There were also negative expectations about the consequences of the accession with regard to finance, labor, health care, and, above all, agriculture.

In 2007, as seen in Hungary from the next Eurobarometer figures, approval of the country's status as a member of the union continued to decline. Although the general support of the EU had never been as high as in 2007, this year showed the lowest support ever in Hungary. 57 percent of EU citizens thought that their country's membership was 'a good thing', and only 15 percent viewed the membership as totally wrong. This indicated a 4 percent rise in approval as compared to the previous Eurobarometer. Contrary to this trend, 40 percent of Hungarians did not consider the EU accession beneficial for the country, and only 37 percent claimed that it was 'good'. Hungarians are among the most pessimistic citizens, both as to the issue of membership (25th place), and to the advantages of membership (27th place in the rank order). 
Hungary was one of the three countries in which people who were of the opinion that accession had not brought about any benefit to their homeland constituted the majority.

Nevertheless, the trust in EU institutions (European Parliament and the Commission) was far stronger than the EU average. For Hungarians, the European institutions are more trustworthy than the national ones. In case of Hungary the reason for this can be found in the fact that the new member states have a short and sometimes negative experience in the 'existing Hungarian capitalism and democracy' and in the consolidation of national democratic political institutions. Citizens' attitude to European symbols (the EU flag, anthem), the Treaty establishing a Constitution for Europe (TCE), and of further accession was remarkably positive. The low acceptance rate of EU membership was primarily due to the widespread perception that the national economy was in a state of crisis. Only a staggering 9 percent of the respondents expressed a positive opinion about the Hungarian economic situation. This is proved by the figures expressing the changes in people's opinion: in 2004 only 10 percent of the population thought the EU to be 'a bad thing', whereas by the spring of 2009 , this percentage had grown as high as 23 percent.

According to the data gathered by the Standard Eurobarometer of Autumn 2008, Hungarian pessimism can be traced already in the answers to the first set of questions, as only 31 percent of the respondents evaluated membership positively, in contrast with the EU average of 53 percent. It is worth noting that in the Autumn of 2004 the percentage of positive responses was still high, at 49 percent. While 60 percent of the EU average citizens claim that the EU imposes its opinion on the member states, only 57 percent of Hungarians share this view. At the same time, in contrast with the EU average of 60 percent, 47 percent of Hungarians think that their country's opinion counts at the European level (Eurobarometer 2008: 31-32).

\section{Growing Euroscepticism}

\section{Post-Euro-introduction Crisis: Italy}

According to the results of a 1999 telephone poll with 2,003 subjects, the majority of Italian citizens was aware of the fact that they would have to cover the costs of the introduction of the Euro, but they still believed that this process would play an important role in the development of the country. 85 percent of the respondents thought that it was good for Italy to be a member of the EU, and 92 percent of them considered the further strengthening the European Integration necessary (Battistelli-Bellucci 2002).

In the year 2000 the exchange rate of the Euro fell against the US Dollar, which was followed by a decrease of Italians' trust in the common currency and 
the common institutions. According to the poll of September 2000 carried out by Ipsos, a mere 58 percent of Italian citizens trusted the Euro, which though higher than the EU average (46 percent), was lower than the figures of two years before by 20 percent. (Il Sole 24 Ore, 2000) Similarly to the opinion poll data of the Ipsos, La Polis also came out with results referring to the decrease in people's trust. In 1999 it was shown that 72 percent of Italians 'trusted very much' the EU institutions, while by 2000, this ratio fell to 57 percent. In 1999 it was only a thin 25 percent of the respondents who thought that belonging to the EU was disadvantageous for the country, and this proportion grew to 35 percent within a year's time. In 1999, the majority (53 percent) of Italians thought that it was for the advantage of the country and its citizens to join the EU, while in 2000 only 41 percent agreed with this statement (Dente 2001: 1054). Nevertheless, institutional reforms were still supported by Italians. This was shown by the data of October 2000 Eurobarometer in which 84 percent of Italian citizens agreed with the creation of a European Constitution. This ratio by far surpassed the EU average (70 percent). The outstandingly positive attitudes towards the EU of the Italian public may have originated from the more apparent disappointment in their own national institutions. Thus, it was the integration that they expected to lead to the economic development of the country. Together with the devaluation of the common currency, the trust in Brussels institutions began to decrease. The temporary crisis of the Euro raised the number of Italian Euro-sceptics measurably (Dente 2001: 1052).

After December 2004, the Commission's interest in the Italian budget situation gradually increased. It became known that the Italian government, similarly to Greece, accessed more credit each year than it reported to Brussels. During that year, the gradually growing government deficit and the structural problems of the Italian economy caused a steadily increasing problem. According to official data of the EU, Italy's government deficit in proportion to the GDP was 3.5 percent in 2003, 3.5 percent in 2004, 4.2 percent in 2005, and 4.4 percent in 2006. At the same time, government debt was 104.3 percent of GDP in 2003, 1013-8 percent in 2004, 106.2 in 2005, and 106.8 percent in 2006. (Eurostat 2008) In 2006, Italian government deficit was the highest in the Euro Zone. Padoa-Schioppa, minister of economy still thought at the end of 2006 that the 2007 budget would give a chance for Italy for remaining below the 3 percent threshold (Corriere della Sera 2006). In April 2006, when an approximate 4 percent deficit in proportion to the GDP was predicted, one of the analyses of the Financial Times even mentioned that Italy would have to leave the Euro Zone. The chance for this, however, was not substantive. Nonetheless, Italy was forced to execute further severe reforms to avoid this threat (La Repubblica 2006). In 2009 , as a consequence of the global crisis, all of the indicators listed above became more extreme. The government debt was as high as 110.5 percent, and 
the government deficit reached 3.7 percent of the GDP. In addition, the government also experienced an GDP decrease of 2 percent.

It became evident that during those years that support for EU membership decreased significantly. In 1991, 78 percent, and in 1999, 62 percent of respondents considered membership a good thing, whereas only 39 percent in 2008 and 41 percent in 2011 agreed with the statement. The proportion of those stating that membership was a bad thing rose from 4 percent to 17 percent between 1991 and 2011, with a rise to 17 percent in 2008 at the peak of the financial crisis.

According to the data gathered by the Standard Eurobarometer in 1993 it was shown that 62 percent of Italians 'tend to trust' the European Commission, while by 2013 this percentage fell to 35 percent. Likewise, in 2003, 57.20 percent of Italians trusted the EU itself, while in 2013, only 23 percent declared this opinion (Eurobarometer 2015).

\section{Italy - Eurosceptic approaches}

In Italy, in spite of the strong pro-European orientation of public opinion, centre-right political parties began to embrace both hard and soft approaches to euroscepticism. Already during the first (1994), but manifestly during the Berlusconi governments, eurosceptic approaches surfaced on a national level (Quaglia 2003). It must be emphasized that the different parties of the centre right coalition (House of Freedom) represented different levels of euroscepticism.

Forza Italia's attitude regarding the EU was very fluid because of its wide range of social background and its rather vague ideological platform, mainly based on the Thatcherian principle of liberal market economy. This attitude emphasised the defence of Italian national interests. As Lucia Quaglia underlined in 2001, 'the position of its leaders on EU issues is still unclear' (Quaglia 2003). Silvio Berlusconi's government demonstrated its soft Euroscepticism in a variety of ways. First, it attempted to re-negotiate the Treaty on the European Union in 1997 in order to join the EMU without fulfilling the convergence criteria. Next, it decided not to participate in the project of the Airbus A400M military transport aircraft (2001). Additionally, members of Berlusconi's like Tremonti and Martino voiced soft Eurosceptic views regarding the introduction of the Euro.

These eurosceptic elements can also be considered as the manifestation of latent individual Euroscepticism in the Italian society (Quaglia 2003: 7-20). Bardi Luciano expressed a similar opinion on Forza Italia: 'Forza Italia is one of the most ambivalent Italian parties with regard to attitudes towards the EU. Documents and manifestoes concerning EP elections are imbued with all the classic elements of pro-European rhetoric. In other documents and positions, however, the party's attitude is more detached and less enthusiastic, especially if compared with that of Italian Catholic and moderate left parties. FI's hesitations are particularly visible on issues having implications for domestic fiscal 
and budgetary policies, and also on foreign policy and security questions, probably in view of the party's preference for a stronger and closer relationship with the United States.' (Bardi 2007: 10) As Conti argues, 'European integration is not at the centre of the ideology of FI, where the market is, instead, the focus' (Conti 2003: 26). Forza Italia joined the European Peoples' Party in 1999. This fact largely contributed to the party gaining political power.

In 1995, the National Alliance (AN) replaced the nationalist and post-fascist Italian Social Movement (MSI). The extreme wing of the MSI created the new party, the MSI-Tricolour Flame, which represented a soft eurosceptic attitude, and the idea of a 'Europe of nations'. The AN maintaining an intergovernmental approach, had a more pro-European attitude than its predecessor, the MSI, in order to realise the political rehabilitation of the party. From the beginning, Gianfranco Fini's main aim was to lead the party toward the political centre, creating a new centre-right Gaullist party. The Statute (1995, Fiuggi) emphasised the 'Europe des patries of de Gaulle'. At the conference of Verona (1998) the final document still proposed the reduction of the significance of national government by increasing the power of the European Parliament' (Bardi 2007: 7). Minister for Telecommunications of the second Berlusconi government, Maurizio Gasparri, emphasised that 'on the one hand there has to be a greater political and democratic legitimisation of the [EU] institutions; on the other hand, there has to be a more balanced promotion of national interests' (Secolo d'Italia 2001; Quaglia 2003: 13-14).

The right-wing, neo-populist Northern League was officially founded in 1991 as a federation of leagues from different northern regions. The party won its first important success in the 1983 elections, when in the region 4.3 percent of voters supported the party. In the second half of the 1980s, however, the centre of the different regional leagues moved over to Lombardy, and their leader, Umberto Bossi, received a seat in Senate in 1987. Bossi who recognised the limitation of the ethno-regionalism, created the Northern League in 1991. The case of this regionalist party is interesting because the $\mathrm{LN}$ changed its position regarding the European integration from a pro-European to a eurosceptic standpoint. The Lombard League, the predecessor of the Northern League, often referred in its political ideology to the European Integration Process. Already in the 1980s they envisioned the token of the independence of Lombardy in a Europe organised on a federative basis. The basis of legitimazing their anti-constitutional, secessionist intentions was provided by the just deepening European Integration. Nevertheless, they conceptualised Europe as a confederation of regions with the broadest possible competencies (concept of Europe of Regions). They considered the Integration as an alternative to national identity. They did not support the development of an integration based on nation-states, centrally governed from Brussels (Diamanti 1993: 161). 
Umberto Bossi, in his book 'Wind of the North', wrote about the birth of regional states and the formation of a 'Europe of Regions,' or a Europe of peoples. Obviously, the constantly growing competence of the Brussels bureaucracy did not fit into this picture. The goal of this party was to create 'the federal Europe of regions' based on the inter-regional (not inter-governmental) principle (Bossi Vimercati 1992). Umberto Bossi envisaged the role of Brussels as threatening the danger of becoming a 'new Rome'.

Nevertheless, in 1993 the League voted in favour of the ratification of the TEU. They considered the establishment of the Committee of the Regions a major step forward that could lead to the transformation of the EP into a federation with two chambers, since, according to their plans, the upper chamber of the European Parliament would fulfil the task of representing the sub-national regions (Diamanti 1993: 166). During the first Berlusconi government in 1994, the Northern League argued that it represented a strong pro-European approach, without any eurosceptic attitude. The LN represented the stance that Italy had to fulfil the convergence criteria in order to enter the Single Currency Zone. Umberto Bossi, the leader of the LN, wrote a letter to the European Commission asking about the possibility for Padania to join EMU (Quaglia 2003: 15; Giordano 2004).

The Northern League, on their Milan Congress in 1997, officially accepted the party's strategy. Indeed, the party's motto suited the previous views of the NL concerning the integration: 'free Padania in a free Europe'. Their goal was to achieve a 'federation based on the cooperation of independent 'small nations'. In this period the NL built their strategy on the fact that Italy was not expected to become a member of the EMU. According to the party this would have strengthened the secessionist inclination in the people of the Northern regions and the formation of a unified Northern identity (Luverà 1997: 88).

The Northern League solidified its eurosceptic stance following Italy's official qualification to join the EMU, which the NL declined to support during parliament voting. After joining the EMU at the millennium, the popular support for the NL decreased significantly (in 2001 3,9 percent and in 20064,1 percent). At the same time, Umberto Bossi and the NL began to express increasingly eurosceptic views (La Padania 2002a; La Padania 2002b).

In 2000, at the Pontida meeting of the NL, Umberto Bossi claimed that the EU did not only threaten large nation states, but also small nations. He expressed his view that emphasising the principle of subsidiarity was only necessary in order to mislead people, as it was only useful for concentrating power at the community level. (Bossi 2000) According to Umberto Bossi, the European left was striving to create a super-state similar to the Soviet Union (Bossi 2001). All over Europe there was a surge of indignation after Bossi called the EU 'the USSR of the West' and a 'Stalinist superstate' (Bossi 2002). Although the Italian government had a traditional pro-Turkish approach, the Northern League stood 
against the opening of the accession process to Turkey because of its Muslim traditions and its large population, despite the fact that the accession process was supported by the main Italian parties. No widespread debate occurred within Italian society over the question of the Turkish accession (EU-25 WATCH No. 2: 127-128). Following the general elections of 2006, the LN formed the opposition and represented a soft eurosceptic attitude. In general they emphasised that the Euro was the cause of the crisis of Northern Italy's small industries.

By 2007, it became clear that the Italian political processes in the short term would result in the formation of a bipolar party system. One of the major signs of this process was that beginning from 2007, the process of fusions between parties accelerated at both sides of the Italian political spectrum. Despite conflicts between ideologically similar parties, the following two years witnessed the rise of two mass parties: People of Freedom and the Democratic Party. The centre-left Democratic Party was established in October 2007 under the leadership of Walter Veltroni following the dissolution of the Democrats of the Left (DS) and the Margherita, as the successor of the Olive-tree Coalition. Veltroni, reacting to the political tensions in Italy, grouped the political goals of the party around four main topics: the environment, agreement between generations, job training, and security. The definition of the position of this new political agent among the European political parties, however, proved to be very difficult and inspired debates among politicians. The party embraced politicians from both from the left wing and from the former Christian Democrats. That is why the Socialist Group in the European Parliament adopted a new name: Progressive Alliance of Socialists and Democrats (S \& D). The Party's Manifesto stated that 'The process of the European unification is still restrained by the strong resistance of nationalistic egoism, which the Democratic Party intends to withstand in order to realise a complete political and democratic integration (Partito Democratico 2008).

The creation of the new centre-right mass party, the People of Freedom, was prepared by Silvio Berlusconi in 2007, and officially finalised during a party congress on 27-29 March 2009 with the fusion of Forza Italia and the National Alliance. The new party still has a wide social background and a rather vague ideological platform. As emphasised in the 'Charter of Values' (Popolo della Libetá 2009) of the People of Freedom, the major ideological issues and goals of the party were its 'Christian' and 'liberal' character, the defence of traditional values as well as of individual responsibility and self-determination, the adherence of the party to the values and the platform of the European People's Party (EPP), and its support for European integration 


\section{Post-EU-accession Crisis: Hungary}

After the EU accession, the 'EUphoria' in Hungarian society was soon replaced by a feeling of disappointment ('EUphobia'). This happened partly because the accession took place later than expected and partly because it did not fulfil the sometimes exaggerated hopes of convergence to the EU average (incomes), let alone the communication deficit regarding the accession. According to data gathered in 2004, the proportion of those who thought that EU membership would be advantageous for Hungary peaked in autumn 2002 at 76 percent, followed by consistent decline (Eurobarometer, 2004b). During the next one and a half years, as 'the requirements set and support offered by the Union became clear', the proportion of optimists decreased by 18 percentage points by spring of 2004, 'when only 58 percent of Hungarian citizens professed to believe that EU membership would be advantageous for the country'. Among the new member states, Hungary still remained one of the three most optimistic countries regarding the advantages expected from EU membership (Eurobarometer, 2004b, 1: 4). Still, it is worth mentioning that Hungary received a chance to become closer to the more developed European nations, because Hungary was less developed than the rest of the EU, in 2004 the GNP per capita in six regions of Hungary was below 75 percent of the EU average (38.25 percent - 60.47 percent), and only that of Central Hungary was 89.24 percent of the EU average.

Post-accession factors have played some role in popularizing Euroscepticism in Hungary following the accession to the EU. During the government of the second conservative coalition (1998-2002), two small parties took a hard Eurosceptic position. The far right Hungarian Justice and Life and the Hungarian Workers' Party adopted a strong opposition to Hungary's EU membership. According to Taggart and Szczerbiak, 'soft Euroscepticism' was taken up by two parties in the then governing coalition, FIDESZ and the Smallholders Party (the smaller partner). The leader of FIDESZ, Prime Minister Victor Orban, was increasingly accepting 'national interest' Euroscepticism (Taggart and Szczerbiak 2001: 16).

It became evident that in most of Hungary's regions, there has not been any economic convergence toward more developed areas of the EU in recent years. Moreover, in the case of some Hungarian regions, a certain amount of divergence can be observed. 
Table 2: GDP per capita (PPP), percentage of the EU average of $\mathrm{NUTS}^{3}$ regions of Hungary

\begin{tabular}{|c|c|c|c|c|c|c|c|}
\hline NUTS 2 & 2003 & 2004 & 2005 & 2006 & 2007 & 2008 & 2009 \\
\hline Central Hungary & 99.9 & 101.2 & 103.3 & 105.1 & 102.9 & 105 & 109 \\
\hline Central Transdanubia & 58.0 & 60.1 & 59.3 & 57.0 & 57 & 58 & 54 \\
\hline Western Transdanubia & 67.7 & 65.9 & 62.6 & 63.2 & 61.5 & 62 & 60 \\
\hline Southern Transdanubia & 45.6 & 45.0 & 43.7 & 42.6 & 42.7 & 44 & 45 \\
\hline Northern Hungary & 40.6 & 41.9 & 41.5 & 40.3 & 40.1 & 40 & 40 \\
\hline Northern Great Plain & 41.8 & 41.4 & 40.1 & 39.1 & 39.4 & 40 & 42 \\
\hline Southern Great Plain & 43.6 & 44.1 & 42.8 & 41.9 & 41.8 & 43 & 43 \\
\hline
\end{tabular}

Source: Eurostat: http://epp.eurostat.ec.europa.eu

The Eurobarometer of October 2006 already clearly showed Hungarian society's disappointment in the EU accession. Since the spring of that year, support for membership has dropped by a further 10 to 39 percent, probably due to the country's domestic political issues such as elections, growing economic problems, and a general feeling of uncertainty (Eurobarometer 2006: 6).

By 2007, the support for membership had further decreased, as is evident in the following Eurobarometer statistics. Although general support of the EU had never been as high as in 2007, that year showed the lowest level of support ever in Hungary's history: 57 percent of EU citizens thought that their country's membership was 'a good thing', and only 15 percent viewed the membership in an entirely negative light. This indicated a 4 percent rise as compared to the previous Eurobarometer. Contrary to these findings, 40 percent of Hungarians did not consider the EU accession beneficial for their country, and only 37 percent claimed that it was 'a good thing'. Hungarians were among the most pessimistic citizens, both with regard to the issue of membership (ranked 25th place) and to the advantages of membership (27th place) (Eurobarometer 2007: 15-16).

According to the data gathered for the Standard Eurobarometer recorded in autumn, 2008, Hungarian pessimism can be traced already in the answers to the first set of questions, as only 31 percent of the respondents evaluated membership positively, in contrast with the EU average of 53 percent. It is worth noting that in autumn of 2004 the percentage of positive responses was still high, at 49 percent. While 60 percent of the EU average citizens claimed that the EU imposed its opinion on the member states, only 57 percent of Hungarians shared this view. At the same time, and in contrast to the EU average of 60 percent, only 47 percent of Hungarians thought that their country's opinion counted at the European level (Eurobarometer 2008: 31-32).

3 In the EU, regional statistics are based on a common classification of territorial units: the Nomenclature of Territorial Units for Statistics (NUTS). NUTS has three regional levels, each with minimum and maximum thresholds for the average population size of the regions. 
It became evident that following the economic and financial crisis support for EU membership has decreased significantly. In 2004, 49 percent of respondents considered membership a good thing, whereas by 2011 only 32 percent stated that this was the case. The proportion of those stating that membership was a bad thing rose from 10 percent to 22 percent between 2004 and 2011, with a further rise to 23 percent in 2009 at the peak of the financial crisis, followed by a fall to 15 percent in the year of the general elections (2010). In 2010, the proportion of respondents stating that EU membership was a 'good thing' was 38 percent as compared to 34 percent in 2009. The change in percentage might have reflected new hope for stronger representation and promotion of national interests on the EU level. The proportion of respondents who thought that membership was 'neither good nor bad' also increased, from 36 percent to 44 percent over the same period.

According to the results of opinion polls conducted by Medián in 2004, 80 percent of the respondents supported Hungary's membership in the EU. Although in 2011 the percentage had fallen to 68 percent, two-thirds of the population still supported Hungary's membership of the EU (Medián 2012). In 2012, the results of an opinion poll conducted by Századvég showed that less than half ( 49 percent) of the respondents said that membership of the EU was beneficial for Hungary and 53 percent did not support further deepening of the European integration process (Origo 2012). According to the data gathered by the Standard Eurobarometer in 2004 it was shown that 64 percent of Hungarians 'tended to trust' the European Union, while by 2013 this ratio fell to 47 percent (Eurobarometer 2015).

\section{0: changing political landscape and debate on the political changes}

Since the general elections of 2010, the Hungarian political landscape has changed significantly due to the high level of protest votes: Fidesz received a more than two-thirds majority in Parliament, the socialists lost their political support, and Jobbik became the third largest party in the country. Moreover, the two more important parties of the transition period, namely the liberals (AFD) and the MDF, disappeared, and the LMP (Lehet Más a Politika, 'Politics Can Be Different'), a new green and anti-corruption party, entered the Parliament.

After the electoral victory of Fidesz Prime Minister Orbán has started to build the so-called system of national cooperation ${ }^{4}$ based on the implementation of a "central political field of force" (Centralis erötér) which would replace the "dual field of force", or the antagonistic dualism between the government and

4 A Nemzeti Együttmúködés Programja. 22. maggio 2010. http://www.parlament.hu/irom39/00047/00047. pdf 
the opposition. A very important element of the process of centralization and strengthening of the state was the drafting and approval of the new constitution (Basic Law). ${ }^{5}$ The political changes and the new constitution have also received criticism from the Venice Commission for Democracy through Law of the Council of Europe, the EU institutions (European Parliament, European Commission, infringement procedures), and the United States of America. (Venice Commission, 2011). According to the critics of the constitutional framework the process was too fast, not transparent, and, as debated by the opposition parties and by EU institutions, considered by the left-wing opposition as a sign of the deconsolidation of liberal democracy and a move from liberal democracy to centralised illiberal or partial democracy. (European Parliament 2011; Friedman 2016)

There is reason to emphasise that the words 'liberal' and 'liberalism' have become used almost as swear words in the Hungarian society and in the political debate, due to the negative attitude in society towards the high level of liberalisation and privatisation of the Hungarian economy, and due to the negative public opinion about the most recent socialist-liberal governments. The main reason for the crisis of liberalism is the decline in support for the political and economic transition, the decline in trust in the function of democracy, the high level of corruption among politicians, and the worsening economic situation of Hungary. In 2011 the European Bank for Reconstruction and Development presented its document on transition economies (the Transition Report), which showed a decline in public support for democracy and the market economy in the countries that joined the EU (EBRD 2011). The decrease in support for democracy was higher in countries hard hit by the financial crisis (Krugman, 2011). Hungary was among the European countries most seriously impacted by the international financial crisis after 2008, and is finding itself in a deep economic recession until 2014. The country has had economic problems since the beginnings of the 21st century. Due to Hungary's high budget deficit, the European Union's excessive deficit procedure has been in place against Hungary since its year of entry to the EU.

In May 2013 the European Parliament made public a draft version of the report on the state of fundamental rights in Hungary prepared by the EP's Committee on Civil Liberties, Justice and Home Affairs (rapporteur MEP Rui Tavares). The draft document was criticised by the Hungarian government saying that it is based on false premises. The case of the so-called Tavares report demonstrated very well the standpoint of the Hungarian government regarding the European Union, which can be defined as Euro-realism, or a soft Euroscepticism based on national interests and national-sovereignty. This case also made clear that a European political space had been created, where domestic political af-

5 Kormany.hu, $\mathrm{n} \mathrm{d} \mathrm{b,} \mathrm{'The} \mathrm{Fundamental} \mathrm{Law} \mathrm{of} \mathrm{Hungary',} \mathrm{http://www.kormany.hu/download/4/c3/30000/}$ THE percent20FUNDAMENTAL percent20LAW percent20OF percent20HUNGARY.pdf 
fairs became European ones, causing several heated debates among European politicians in different institutions of the EU (European Parliament 2013). FIDESZ's attitude regarding the EU focusing on the defence of Hungarian national interests has become very fluid, floating between pro-EU and Eurosceptic standpoints because of the wide range of its supporters' social background and the party's rather vague ideological platform (Fidesz 2009; BBC 2012; Fidesz 2011, Euractiv 2013a; 2013b; 2013c; Hiradó 2013; Hungarian Spektrum 2013, Arató - Koller 2015).

During the second conservative government, Jobbik still expressed semi-hard or sometimes hard Euro-sceptic standpoints, while pro-European/euro-optimist positions were more common among members of the Democratic Coalition led by a highly criticised ex-socialist party leader, Ferenc Gyurcsány, and the LMP. According to a research carried out by the Hungarian Europe Societz, Fidesz 'covers internal divisions', as the research identified two wings in Fidesz: 'a less visible, Euro-constructive one and a noisier, Euro-pessimist one led by Viktor Orbán' (Európa Társaság 2013: 4). At the national level, the MSZP carefully avoids taking a position in debates concerning the future of the EU. Only the LMP has a coherent federalist vision of the EU (in its 2010 electoral manifesto) (Európa Társaság 2013: 4).

As a result of the 2010 parliamentary elections, Jobbik became the third main party in Hungary, with 17 percent of the votes. Its popularity is highly connected to the economic problems in Hungary (in 2010 the GDP was -6.3 percent, and the unemployment rate was above 11 percent), and to the disappointment in the process of democratisation and Europeanisation due to the high level of corruption. The characteristic features of Jobbik's extreme rightist ideology are anti-democratic feelings, nationalism, chauvinism, and racism. They usually do not reject the application of radical methods in resolving social problems.

Jobbik, like extreme right nationalistic parties in general, represents a semi-hard Euro-sceptic standpoint in not supporting the further deepening of integration. The party appeared to see the integration as standing for a supranational political structure that aims at the renewed suppression of small countries. In Hungary, the reason for growing Euro-scepticism is probably the lack of economic growth following the accession (2004) and the disillusionment with the process of democratisation and liberalisation (Vona 2009; Teol 2009).

Accession to the EU brought about a serious trauma for Hungary, known as the "post-accession crisis". Under the influence of the change of the regime, there was, on the one hand, a social-structural crisis, because the economic deficit was transformed into social deficit during the process of crisis management. On the other hand, the new democratic state had no time to develop fully, and thus remained weak. Fast-paced democratization led to a serious social deficit, namely to economic and social insecurity. When Hungary's accession to the EU was achieved, the state and civil society were still weak. It was this 
fact that caused trauma; the country was not ready for accession either from the point of view of societal capacity or of the state of development of the institutional structure. In addition, the onset of the so-called "accession and reform exhaustion" has resulted in the rise of populism (Ágh 2008: 94-95). In 2010, the new governing coalition answered to this challenge with the strengthening and centralising state capacities, and with a quiet populist approach based on emphasised promotion of national sovereignty.

\section{Italy - Third Republic?}

There is still the question of whether following the resignation of Berlusconi (2011) as prime minister, the transition to the Third Republic has started or not. But we must emphasise that there is a changing political landscape, the end of bipolarism, and the fragmentation of the party system (Terza Forza, M5S) has started again. Due to the wave of corruption scandals and to Italians' eroding confidence in their politicians, the Italian party-system transformed significantly.

The birth of a new populist, anti-political movement, the Five Stars Movement (M5S) was a clear symptom of the deep crisis of Italian representative democracy. This political movement, taking advantage of the possibilities of direct democracy offered by the web, in 2013 became the third largest political party in the country, gathering 26 percent of the votes at general elections and filling the political gap left behind by PdL and LN. Created following the beginning of financial crisis, M5S has positioned itself in opposition to existing political parties and the traditional elites. Its aim is destroying the established party system. We can observe that since the beginning, it has represented the anger of the Italian electorate.

M5S has an unclear picture of EU and embraces soft eurosceptic standpoints. In 2013 it started to prepare a referendum on EU membership and on the Euro. Beppe Grillo said that "Europe should be rethought," It is more against the Euro and the EU-imposed austerity policies.

Following the resignation of Berlusconi in 2011, the governments of Monti and Letta have clearly returned to the traditional EU-policy of Cristian Democrats supporting more an integration in terms of a banking union, fiscal union, and Eurobonds. We can easily observe a growing gap between the Italian political elite and Italian public opinion. The ambitious Renzi government has started to implement the political and economic reforms in order to lead the country toward the "third republic".

\section{Conclusion}

Both Italy and Hungary have had difficulties of different types of transitions, and both have been hit hard by financial and economic crises. The two countries semi-peripheral positions have been strengthened by the economic and 
financial crisis. Jobbik and M5S are the clear symptoms of the deep crisis of representative democracy in Hungary and Italy. There is growing populism and euroscepticism due to the disadvantages of joining the EU and the Euro-zone, and due to the persistent democratic deficit of the EU. As a consequence, the EU has extended its competences to override national governments on timely issues, such as pension reform. In the case of Hungary, we can observe the process from EU-foria to EU-fobia (Euroscepticis). In the case of Italy, we can trace the process from Euro-enthusiasm to Euro-delusion.

\section{References}

Ágh, A. (2008): Kitekintés a Kelet-Közép-Európai Konszolidációra. Politikatudományi Szemle. Review of Political Science 2008/1, 95-11.

Arató, Krisztina - Koller, Boglárka (2015): Magyarország és az Európai Unió. In Körösényi András (szerk.) A magyar politikai rendszer - negyedszázad után. 428 p. Budapest: Osiris Kiadó. 377-400.

Bardi, L. (2007): Italian Political Parties and the European Union: Implications for Party Change. Paper presented at the annual meeting of the International Studies Association 48th Annual Convention, Hilton Chicago, CHICAGO, IL, USA, Feb 28, 2007: http://www.allacademic. com/meta/p179154_index.html.

Battistelli, F. - Bellucci, P. (2002): L'identitá degli italiani. Euroscetticismo e europportunismo. In Il Mulino. 2002. 1: 77-85.

BBC (2012): Hungarian PM Viktor Orbán denounces EU's 'colonialism', 6 March 2012, http:// www.bbc.co.uk/news/business-17394894.

Bindi, F. - Grassi, S. (2006): The Parliament of Italy It Would Be Active Player? 2006.

Bossi, U. (2000): Intervento del Segretario Federale. On. Umberto Bossi, Pontida, 4. giugno 2000. www.leganord.org/a_2_discorsi_pontida_4_06_2000.html.

Bossi, U (2001): Intervento del Segretario Federale, On. Umberto Bossi. Pontida, 17. giugno 2001. www.leganord.org/a_2_discorsi_pontida_17062001.html.

Bossi, U. - Vimercati, D. (1992): Il vento del Nord. Sperling \& Kupfer. Milano.

Ciampi C. A. (2000b): Verso una costituzione europea. In Europa Europe. 4-5: 181-187.

Ciampi, C. A. (2000a): Approfondire e allargare l'Europa. In II Mulino. 2: 203-208.

Comelli, M - Darnis, J. (2008): Europa e legittimità democratica: due proposte. 08/08/2008 http://www.affarinternazionali.it/articolo.asp?|D=915.

Conti N. (2003): Party Attitudes to European Integration: A Longitudinal Analysis of the Italian Case. SEl Working Paper No 70. 2003. by the Sussex European Institute. http://www.sussex. ac.uk/sei/documents/wp70.pdf. 
Conti, N. - Memoli, V. (2010): Italian Parties and Europe: Problems of Identity, Representation and Scope of Governance in the Euromanifestos (1989-2004) Perspectives on European Politics and Society 11 (2):167 - 182.

Conti, N. (2006): Party conflict over European integration in Italy: a new dimension of party competition? Journal of Balkan and Near Eastern Studies 8 (2): 217-233.

Corriere della Sera (2002): Umberto Bossi: mobiliteró i popoli contro l’Europa stalinista. Corriere della Sera. 1 March 2002. www.corriere.it.

Corriere della Sera (2006): Deficit-Pil sotto il 3 percent con la Finanziaria http://www.corriere. it/Primo_Piano/Economia/2006/12_Dicembre/14/bce.shtml.

D'Alema, M. - Cuperlo, G. (1997): La grande occasione. L'Italia verso le riforme. Mondadori. Milano.

D’Alema, M. (1998): La nostra politica europea. Europa Europe 3: 29-33.

Dente, B. (2001): Riforme e controriforme amministrative. Il Mulino 6: 1050-1059

Diamanti, I. (1993): L'Europa secondo la Lega. Limes 4: 161-175.

Dini, L. (2000): Le regole dell'avanguardia. Europa Europe 4-5: 159-161.

Dipartimento Politiche Comunitarie (2006): Emma Bonino http://www.politichecomunitarie.it/ DefaultDesktop.aspx?doc=14151.

EBRD (2011): Transition Report: Crisis in Transition: The People's Perspective.

EBRD (n.d.): Transition Report 2012, Document of the European Bank for Reconstruction and Development, 'Strategy for Hungary', as approved by the Board of Directors at its meeting on 11 October 2011: http://www.ebrd.com/downloads/country/strategy/hungary.pdf.

EU-25 Watch No 3, 2006. Institut für Europäische Politik, Berlin: http://www.eu-consent.net/ library/EU25Watch/EU-25_Watch-No3.pdf.

EU-25 WATCH No. 1. December 2004 Institut für Europäische Politik, Berlin: http://www.eu-consent.net/library/EU25Watch/EU-25_Watch-No1.pdf.

EU-25 WATCH No. 2. 2006. Institut für Europäische Politik, Berlin Institut für Europäische Politik, Berlin.

EU-25/27 WATCH No. 5. 2007. Institut für Europäische Politik, Berlin: http://www.eu-consent. net/library/EU25Watch/EU-25_Watch-No1.pdf.

EU-27 WATCH No. 8. Institut für Europäische Politik, Berlin: http://www.eu-consent.net/library/ eu25watch/EU-27_Watch_No8.pdf.

EU-27 Watch. No.7. Institut für Europäische Politik, Berlin: http://www.eu-consent.net/library/ eu25watch/EU-27_Watch_No7.pdf.

Euractiv (2013a) Hungary and the Rule of Law - Statement of the European Commission in the Plenary Debate of the European Parliament', 17 April 2013, European Commission, SPEECH/13/324, http://europa.eu/rapid/press-release_SPEECH-13-324_en.htm?locale=en.

Euractive (2013b): Commission accuses Hungary of transgressions, 18 April 2013: http://www. euractiv.com/future-eu/commission-lists-hungary-transgr-news-519202.

Euractiv (2013c): Viktor Orbán angry at EU's criticism of Hungary's democratic values, 3 July 2013: http://www.euractiv.com/video/viktor-orban-angry-eus-criticism-529065. 
Eurobarometer (2004): The future Europea Constitution. June-July 2004. Flash Eurobarometer: http://ec.europa.eu/public_opinion/flash/fl159_2en.pdf.

Eurobarometer (2004a): The social situation in the European Union: http://epp.eurostat. ec.europa.eu/cache/ITY_OFFPUB/KE-AG-04-001/EN/KE-AG-04-001-EN.PDF.

Eurobarometer (2004b): Public opinion in the candidate countries, National Report, Executive summary, Hungary, http://ec.europa.eu/public_opinion/archives/eb/eb61/exec_hu.pdf.

Eurobarometer (2005): National Report, Executive Summary, Italy, Eurobarometer 63: http:// ec.europa.eu/public_opinion/archives/eb/eb63/eb63_exec_it.pdf.

Eurobarometer (2006): National Report, Executive Summary, Italy, Eurobarometer 65. 2006 spring http://ec.europa.eu/public_opinion/archives/eb/eb65/eb65_it_exec.pdf.

Eurobarometer (2006, Autumn): Standard Eurobarometer 66, Public opinion in the European Union: http://ec.europa.eu/public_opinion/archives/eb/eb66/eb66_highlights_en.pdf.

Eurobarometer (2007), National Report, Executive Summary, Italy, Eurobarometer 67. 2007 spring: http://ec.europa.eu/public_opinion/archives/eb/eb67/eb67_it_exec.pdf.

Eurobarometer (2007, Spring): Standard Eurobarometer 67, Public opinion in the European Union: http://ec.europa.eu/public_opinion/archives/eb/eb67/eb_67_first_en.pdf.

Eurobarometer (2008): National Report, Executive Summary, Italy, Eurobarometer 69: http:// ec.europa.eu/public_opinion/archives/eb/eb69/eb69_it_exe.pdf.

Eurobarometer (2008, Autumn): Standard Eurobarometer 70, Public opinion in the European Union: http://ec.europa.eu/public_opinion/archives/eb/eb70/eb70_first_en.pdf.

Eurobarometer (2015): http://ec.europa.eu/public_opinion/cf/showtable. cfm?keyID=2193 \& nationID=8,\&startdate=2003.11 \& enddate=2015.05; http://ec.europa. eu/public_opinion/cf/showtable.cfm?keyID=2193 \& nationID=8,\&startdate $=2003.11$ \& enddate=2015.05; http://ec.europa.eu/public_opinion/cf/showtable. cfm?keyID=2193 \& nationID=22,\&startdate=2004.10 \& enddate=2015.05

Európa Társaság (2013): Where Does the PERC Index Stand? Or: From EU Destructives to Federalists: Relationship of the Hungarian Parties to the European Union, Executive Summary, http://www.europatarsasag.hu/images/2013Jan/PERC percent20 percent20executive percent20summary.pdf.

European Parliament (2011): European Parliament resolution of 10 March 2011 on media law in Hungary: http://www.europarl.europa.eu/sides/getDoc.do?pubRef=-//EP//TEXT+TA+P7-TA2011-0094+0+DOC+XML+V0//EN.

European Parliament (2013): MEPs voice concerns over constitutional changes in Hungary, Justice and home affairs, 17 April 2013, http://www.europarl.europa.eu/news/en/headlines/ content/20130416STO07356/html/MEPs-voice-concerns-over-constitutional-changes-in-Hungary.

Eurostat (2008): Economy 2008: http://epp.eurostat.ec.europa.eu/cache/ITY_OFFPUB/KS-CD-07-001-01/EN/KS-CD-07-001-01-EN.PDF.

Fabbrini (2009): The Transformation of Italian Democracy. Bulletin of Italian Politics 1(1): $29-47$. 
Fidesz (2009): Igen, Magyarország többre képes: http://static.fidesz.hu/download/yar/program2009_magyar.pdf.

Fidesz (2011): EU stronger than at start of Hungarian presidency, 5 July 2011, (MTI-fidesz.hu): http://www.fidesz.hu/index.php?Cikk=165020.

Friedman, George (2016): Hungary, Poland and illiberal democracy: https://www.euractiv.com/ section/global-europe/opinion/hungary-poland-and-illiberal-democracy/.

Gabel, M., Whitten G. (1997): Economic Conditions, Economic Perceptions, And Public Support For European Integration, Political Behaviour 19: 81-96.

Gabel, M (1998): Public support for European Integration: An Empirical test of five Theories, Journal of Politics vol. 60.

Giordano, B. (2004): The politics of the northern league and Italy's changing attitude towards Europe. Perspectives on European Politics and Society 5 (1): 61-79.

Hagemann, S. - Hix, S. (2009): Could Changing the Electoral Rules Fix European Parliament Elections? http://personal.lse.ac.uk/hix/Working_Papers/Hix_Hagemann-Can_EP_Elections_Be_Fixed-14Jan09.pdf.

Hegedűs, I. (2005): Magyarország és a magyar média belépése az Európai Unióba:

/Accession to the EU of Hungary and the Hungarian media / www.mediakuato.hu /media researcher/ 2005. 05. 02.

Hirado (2013): EP approves Tavares report on fundamental rights in Hungary, http://www.hirado. hu/Hirek/2013/07/03/19/EP_approves_Tavares_report_on_fundamental_rights_in.aspx.

Horváth, J. (2000): Követő külpolitika. Az olasz Európa-politika a második világháború után. In Kiss J. László (ed), A tizenötök Európái. Közösségi politikák - nemzeti politikák. Osiris, 193-226.

Hungarian Spektrum (2013): Viktor Orbán's answer to the Tavares report, http://hungarianspectrum.wordpress.com/2013/07/04/viktor-orbans-answer-to-the-tavares-report/comment-page-1/.

Ignazi, P. (2002): L'intramontabile fascino del populismo. Il Mulino 1: 59-66.

Il sole 24 ore. 2000. október 14. 1-3.

Juhász, J. and Tálas, P. (2008): A szélsőjobboldal, a jobboldali radikalizmus és a populizmus előretörésének okairól Kelet- és Közép-Európában' in Európai Tükör, 2008/4, 116-124.

Kégler, Á. (2004): Európai Parlamenti kampány: Hazabeszélnek', Figyelő 2004/15, 20-21.

Kopecky, P. and Mudde, C. (2002): The two sides of Euroscepticism: Party Positions on European Integration in East Central Europe, European Union Politics vol. 3.

Kormány, A. (2006): Vélemények az EU tagságról és annak következményeiről, in Európai Tükör, 2006/10: 89-97.

Kormany.hu, n d b, The Fundamental Law of Hungary, http://www.kormany.hu/download/4/ c3/30000/THE percent20FUNDAMENTAL percent20LAW percent20OF percent20HUNGARY. pdf.

Kormany.hu, n.d.a, 'The history of Hungarian EU membership', http://eu.kormany.hu/the-history-of-hungarian-eu-membership. 
Körösényi, András and Patkós, Veronika (2015): Liberális és illiberális populizmus: Berlusconi és Orbán politikai vezetése. Politikatudományi Szemle, 24 (2): 29-54. ISSN 1216-1438.

Krugman, P. (2011): Depression and Democracy, The New Yourk Times, 11 December 2011. http:// www.nytimes.com/2011/12/12/opinion/krugman-depression-and-democracy.html?_r=0.

La Padania (2002/a): Che Ue vogliamo, questione fondamentale: www.lapadania.com/2002/ gennaio/06/06012002p03a4.htm.

La Padania (2002b): Francesco Speroni: Con la devolution parte il vero cambiamento: www. lapadania.com/2002/gennaio/06/06012002p05a2.htm

La Repubblica (2002): Ruggiero rompe il silenzio Con la Lega non potevo stare: http://www. repubblica.it/online/politica/berlueuropa/ruggiero/ruggiero.html.

La Repubblica (2006): Fmi: L'Italia cresce meno. Dure sfide per il nuovo governo: http://www. repubblica.it/2006/04/sezioni/economia/conti-pubblici-1/previsioni-fmi/previsioni-fmi.html.

Luverà, B (1997): La politica estera della Lega. Limes 1997. 2: 87-96.

Mair, P. (2000): The Limited Impact of Europe on National Party System in West European Politics, 27-51.

Marján, A. (2006): Az EU-bővítés: vissza- és előretekintés', in Európai Tükör, 2006/11, 5-16.

Mayr, W. (2009): Hungary's Peaceful Revolution: Cutting the Fence and Changing History, 29 May 09, http://www.spiegel.de/international/europe/hungary-s-peaceful-revolution-cutting-the-fence-and-changing-history-a-627632.html.

Medián (2005): Jogállamiság, demokrácia, parlamentarizmus - a, Eötvös Károly Intézet és az ELTE ÁJK Jogszociológiai Tanszéke megbízásából.

Medián (2012): Egy szabadságharc frontvonalai: A közvélemény az IMF-tárgyalásokról és az EU-ról, 2012. március 19, http://www.median.hu/object.90dcfe43-2f4b-448d-adb4-6bb74fdf1129. ivy.

Molnár, Anna (2013): EU membership and the question of Hungary's sovereignty: Ideas of the European Union before and following the crisis" In: Lise Rye (ed.) Distant voices: Ideas on democracy and the Eurozone crisis. Trondheim: Akademika forlag, 75-105.

Molnár, Anna (2012): Ideas of Europe in Italian political discourse. ACADEMIC AND APPLIED RESEARCH IN MILITARY SCIENCE 11 (1): 81-105.

Molnár Anna (2011): Idea of Europe in Hungarian political discourse In: Cláudia Toris Ramos (ed.) Ideas of Europe in National Political Discourse. Bologna: Il Mulino, 229-263.

Napolitano, G. (2007): Discorso del Presidente della Repubblica Giorgio Napolitano in occasione della visita al Parlamento Europeo" 14 Febbraio 2007 Parlamento Europeo: http://foreignpolicy.it/cgi-bin/news/adon.cgi?act=doc \& doc=2638 \& sid=17.

Napolitano, G. (2008): Dichiarazione del Presidente Napolitano sull'esito del referendum in Irlanda relativo alla ratifica del Trattato di Lisbona. 13-06-2008: http://www.quirinale.it/ Comunicati/Comunicato.asp?id=36155.

Navracsics, T. (1997): A missing debate? Hungary and the European Union, Sussex European Institute SEI Working Paper, No. 21, Sussex European Institute http://www.sussex.ac.uk/sei/ documents/wp21.pdf. 
Origo (2012): Századvég - kedvezőtlenül alakul Magyarország uniós tagságának a megítélése, 2012. március 19, http://www.origo.hu/itthon/20120131-szazadveg-kedvezotlenul-alakul-magyarorszag-unios-tagsaganak-a-megitelese.html.

Padoa-Schioppa, T. (2005): Non mentire sul no francese, Il Mulino, luglio-agosto 2005. 636-643.

Partito Democratico (2008): Manifesto dei Valori del Partito Democratico, Approvato il 16 febbraio 2008, http://www.ulivo.it/allegatidef/Manifestodeivalori44883.pdf.

Pistone, S. (ed.): L'Italia e L'Unitá Europea, Torino, Loescher,1982.

Politics (2013): EP approval of Tavares report European left-wing's scheme, Orbán says, 5 July 2013, http://www.politics.hu/20130705/ep-approval-of-tavares-report-european-left-wings-scheme-orban-says/.

Popolo della Libetá (2009): Carta dei Valori, http://www.ilpopolodellaliberta.it/notizie/15346/ carta-dei-valori.

Prodi (2006): Celebrazioni dei 50 anni dei Trattati di Roma. Discorso del Presidente del Consiglio Romano Prodi. 23 March 2007, Senato della Repubblica, 23 marzo 2007. http://foreignpolicy. it/cgi-bin/news/adon.cgi?act=doc \& doc=2735 \& sid=17.

Quaglia, L. (2003): Euroscepticism in Italy and Centre-Right and Right Wing Political Parties." RSCAS, European University Institut. SEl Working Paper No: 60.

Senato (2009): Elezioni europee: è legge la soglia di sbarramento al 4 per cento, 18 febbraio 2009 http://mobile.senato.it/notizie/8766/163120/164601/165376/165378/gennotizianew.htm

Serricchio, F.: Italian Citizens and Europe: Explaining the Growth of Euroscepticism. Bulletin of Italian Politics 4 (1): 115-134.

Sükösd, M. (2005): Kommunikációs deficit Magyarország Európai Uniós csatlakozásának média-bemutásában : megoldási irányok és nyilvánosság-modellekok, in Médiakutató 73-83.

Taggart, P. and Szczerbiak, A. (2001): Parties, Positions and Europe: Euroscepticism in the EU Candidate States of Central and Eastern Europe, Sussex European Institute Working Paper No. 46, Sussex European Institute, http://www.sussex.ac.uk/sei/documents/wp46.pdf.

Tavares, R (2013): Draft Report on the situation of fundamental rights: standards a nd practices in Hungary, European Parliament, Committee on Civil Liberties, Justice and Home Affairs, http://www.europarl.europa.eu/sides/getDoc.do?pubRef=- percent2F percent2FEP percent2F percent2FNONSGML percent2BCOMPARL percent2BPE-508.211 percent2B02 percent2BDOC percent2BPDF percent2BVO percent2F percent2FEN.

Teló, M. (1996): L'Italia nel processo di costruzione europea. In: Storia dell'Italia Repubblicana, vol.3. Toroino, Einaudi, 1996. 195-197.

Teol (2009): A Jobbik felszámolná a poronty bizniszt, 7 September 2009, http://www.teol.hu/ tolna/kozelet/a-jobbik-felszamolna-a-poronty-bizniszt-255753.

Uitz, R. (2008): Hungary in: Grigorij Mesežnikov, Ol'ga Gyárfášová, and Daniel Smilov: Populist politics and liberal democracy in Central and Eastern Europe. Bratislava, Institute for Public Affairs. http://www.ivo.sk/buxus/docs/publikacie/subory/Populist_politics.pdf.

Vaciago, G. (2001): Stare in Europa, ovvero i vincoli dell'unione. Il Mulino 2001. 2: 206-210. 
Venice Commission (2011): Strasbourg, 20 June 2011, Opinion no. 621 / 2011, CDL-AD(2011)016 Or. Engl. European Commission for Democracy through Law (Venice Commission) Opinion on the new Constitution of Hungary, Adopted by the Venice Commission at its 87th Plenary Session, Venice, 17-18 June 2011.

Vona, G. (2009): A Magyar Gárda nem adja fel, 3 February 2009, http://www.mno.hu/ portal/606865?searchtext=Vona percent20G percentC3 percent A1bor.

Anna Molnár is an Associate Professor at the National University of Public Service (Budapest) and Head of the Department of International Relations and Diplomacy. She is the Head of International Public Management bachelor's program. She was the Head of Programme of MA in international studies at the University of Pannonia (Institute of Social Sciences and International Studies, Veszprém) between 2010 and 2013. She received her Ph.D. in international relations from the Corvinus University of Budapest (2003). Her published papers cover a wide range of topics whose central theme is focusing on security studies, EU CFSP/CSDP, europeanization of Hungary, the European Union's Mediterranean policy and on the Italian history and politics. She gives courses at Hungarian and foreign universities on European integration, international studies and Italian politics. She had a Bolyai Research Fellowship of the Hungarian Academy of Science (2007-2010).Email: Molnar.Anna@nke-uni.hu. 